\title{
ANALISIS PROFIL ASAM LEMAK DAGING AYAM PETELUR AFKIR YANG DIFERMENTASI SECARA TRADISIONAL BALI MENGGUNAKAN GAS CHROMATOGRAPHY-MASS SPECTROMETRY (GC-MS)
}

\author{
I. A. Okarini ${ }^{1 *}$, H. Purnomo, ${ }^{2}$ L. E. Radiati ${ }^{2}$, dan N. M. Suaniti ${ }^{3}$ \\ ${ }^{1}$ Fakultas Peternakan, Universitas Udayana, Bukit Jimbaran, Badung, Bali, Indonesia. \\ ${ }^{2}$ Fakultas Peternakan, Universitas Brawijaya, Malang, Jawa Timur, Indonesia, \\ ${ }^{3}$ Program Studi Kimia,, Fakultas Matematika dan Ilmu Pengetahuan Alam, Universitas Udayana, \\ Bukit Jimbaran, Badung, Bali, Indonesia. \\ *Email: i.aokarini@yahoo.com
}

\begin{abstract}
ABSTRAK
Penelitian ini bertujuan untuk mengetahui profil asam-asam lemak pada produk fermentasi daging ayam petelur afkir (bagian dada, Musculus pectoralis superfisialis), menggunakan teknik Gas Chromatography Mass Spectrophotometry (GCMS). Ayam petelur afkir strain Isa Brown, diperoleh dari peternakan lokal di Tabanan, Denpasar, dan Gianyar - Bali setelah periode peneluran, umur 76 minggu. Daging dipotong-potong kecil, dicampur dengan bumbu halus yang terdiri dari lengkuas, ketumbar, bawang putih, gula merah, garam, lada putih dan minyak kelapa, serta dibungkus dengan upih. Selanjutnya, dijemur di bawah matahari (proses fermentasi alami) sampai 5 hari. Data profil asam lemak diintegrasikan dan disajikan secara deskriptif. Hasil penelitian menunjukkan bahwa komponen bioaktif asam lemak dalam daging ayam hasil fermentasi seperti asam oleat, asam palmitat, dan asam linoleat lebih tinggi dari kontrol tetapi asam stearat lebih rendah, serta kolesterol yang paling rendah pada akhir pengeringan.
\end{abstract}

Kata kunci: daging ayam, fermentasi, GCMS, profil asam lemak

\begin{abstract}
This study was aimed to determine the fatty acids profile in fermented products of chicken breast meat (Musculus pectoralis superficialis) of spent hen layer using Gas Chromatography Mass Spectrophotometric technique. The chicken used was of Isa Brown strain after a period of laying of 76 weeks which was obtained from some local farms in Tabanan, Denpasar, and Gianyar - Bali. The chicken meat was cut into small pieces then mixed with ground spices concisting of galangal, coriander, garlic, brown sugar, salt, white pepper and coconut oil. The batter meat was mixed evenly and then wrapped with upih, in which both ends were tied with a rope followed by drying under the sun for 5 days (natural fermentation process). The profile of the fermented chicken meat was integrated and presented descriptively. The results showed that the fermented meat contained higher bioactive component of fatty acids such as oleic acid, palmitic acid and linoleic acid compared to that of the control, but lower stearic acid content. It was also evident that the cholesterol content was the lowest at the end of drying.
\end{abstract}

Keywords: chicken meat, fatty acids profile, fermentation, GCMS

\section{PENDAHULUAN}

Daging ayam sangat populer bagi konsumen Indonesia, dan khususnya di Bali telah tersedia daging ayam lokal, daging ayam petelur afkir dan daging ayam pedaging (broiler) sebagai sumber nutrisi yang relatif murah. Namun dari ketiga jenis ternak ayam ini memiliki manfaat sesuai kebiasaan masyarakat Bali, untuk keperluan upakara atau untuk menu sehari-hari. Pada umumnya saat ini produk daging terfermentasi alami yang diproduksi di Bali masih berbasis daging dan lemak babi, sehingga belum dapat dinikmati oleh semua lapisan masyarakat. Oleh karena itu perlu dicoba membuat produk daging terfermentasi menggunakan daging ayam, dan dapat diterima oleh semua lapisan masyarakat luas.

Fermentasi daging telah menjadi subjek penelitian intensif selama dekade terakhir, dimana terjadi perubahan fisiko-kimia, mikrobiologis dan biokimia (Casaburi et al., 2007). Pengembangan produk daging fermentasi tradisional dapat merupakan target dan strategi yang menguntungkan industri pengolahan daging untuk mengenalkan fungsi fisiologis (Arihara, 2006 a; b; Arihara dan Ohata, 2008; Vass et al., 2008). Beberapa faktor yang berpengaruh pada 
proses fermentasi seperti variasi jenis dan jumlah bahan baku, kondisi fermentasi (spontan atau penambahan kultur starter) dan pengeringan yang diperpanjang akan mengarah pada keragaman mikroorganisme yang mendominasi habitatnya (Paramithiotis, et al., 2010). Salah satu sumber proteinase yang murah dan mudah cara memperolehnya yaitu protease dari bakteri asam laktat (BAL), secara luas digunakan untuk memproduksi bioaktif peptida. Peptida alami dari BAL berpotensi kesehatan, terutama aman dari racun, spektrum yang luas pada tindakan terapi, dan kurangnya efek samping, bila dibandingkan dengan obat sintetik dan baik diserap dalam saluran usus (Agyei dan Danquah 2011). Protease mikroorganisme memberikan beberapa keunggulan dibandingkan protease dari sumber lain. Biaya budidaya bakteri relatif rendah (kebutuhan gizi minimal, waktu pematangan singkat), dan khususnya protease BAL yang terdapat pada bagian membran sel, dan untuk membuat protokol pemurnian relatif mudah dan murah. Selanjutnya BAL dan produknya dianggap aman (umumnya diakui sebagai kondisi aman, GRAS) (Agyei dan Danquah, 2011).

Berdasarkan beberapa permasalahan di atas maka perlu untuk mempelajari dan mendokumentasikan komponen bioaktif (asam lemak) produk daging ayam terfermentasi alami (tanpa penambahan kultur starter mikroorganisme, memanfaatkan mikroorganisme alami bahan baku).

\section{MATERI DAN METODE}

\section{Pelaksanaan penelitian}

(analisis kimiawi) di Laboratorium Kimia Pangan, Fakultas Teknologi Pertanian Universitas Udayana, Kampus Denpasar dan di Laboratorium Forensik POLDA Bali di Jalan Gunung Agung Denpasar, Bali.

\section{Bahan dan alat penelitian}

Proses pembuatan bebontot daging ayam petelur afkir bagian dada (Musculus pectoralis superficialis), digunakan untuk produk daging terfermentasi, tanpa penambahan lemak dan kultur starter. Bumbu-bumbu terdiri atas bawang putih $25 \%$, laos/lengkuas segar $35 \%$, ketumbar butiran $15 \%$, merica putih butiran $2 \%$, garam dapur $8 \%$, gula merah/gula kelapa $10 \%$ dan $5 \%$ minyak goreng, digerus atau dihaluskan dan sebanyak $10 \%$ dari berat daging ayam, dicampur sampai rata dengan daging yang telah dipotongpotong bentuk kubus. Pelepah daun pinang kering (upih, bahasa Bali) sebelumnya dicuci dan dikeringkan terlebih dahulu untuk bahan pembungkus. Dipersiapkan para-para untuk tempat menggantungkan, dijemur dan dipasang termometer basah-kering. Selanjutnya adonan dibungkus dengan upih dan kedua ujung pembungkus diikat dengan tali dan digantung pada para-para untuk selanjutnya dijemur langsung di bawah sinar matahari selama 5 hari.

\section{Penentuan profil asam lemak produk daging ayam terfermentasi}

Preparasi sampel produk fermentasi daging ayam, dicincang bentuk kubus 1,5-2 cm dan dicampur, kemudian dihomogenkan menggunakan penggiling dan dikeringkan dalam oven $\left(50^{\circ} \mathrm{C}\right.$ selama 12 jam). Sampel kering dihaluskan dengan mortar menjadi bubuk/tepung halus secara terpisah, kemudian disaring dengan membran $(250 \mu \mathrm{m})$. Seratus miligram sampel halus dicampur dengan $1 \mathrm{~mL}(1000 \mu \mathrm{L})$ metanol absolut atau heksana, kemudian disentrifugasi (Beckman Coulter Avanti JE) pada 15000 rpm selama 5 menit pada suhu kamar. $100 \mu \mathrm{L}$ supernatan ditambahkan ke $900 \mu$ Lmetanol absolut, kemudian disentrifugasi pada $15000 \mathrm{rpm}$ 5 menit dan dibiarkan pada suhu ruang sebagai yang dijelaskan oleh Oyugi et al. (2011) dengan sedikit modifikasi. Supernatan yang dihasilkan secara langsung digunakan sebagai sampel akhir dan satu mikroliter supernatan siap untuk diinjeksikanke alat GC-MS yang telah diprogram. Analisis ekstrak sampel di dilakukan dengan menggunakan satu set peralatan kromatografi gas (GC) Agilent Technologies 6890 N (G.1540M) (Palo Alto, CA, USA) yang dihubungkan dengan detector (Agilent Technologies 5973 Inert Mass Selective Detector) untuk menghasilkan data, dilengkapi dengan HP5MS kolom (id.30mx 0,32mm). Spektrum massa yang diperoleh di bawah (ionizations mode) pada kondisi dampak elektron (Electron Impact, EI) $70 \mathrm{eV}$ dan sumber ion diadakan $230^{\circ} \mathrm{C}$. Rentang scan pada basis data $\mathrm{m} / \mathrm{z}$ 40-400. Suhu injektor diprogram pada $250^{\circ} \mathrm{C}$, Suhu kolom dalam Oven GC diprogram dari $70^{\circ} \mathrm{C}$ ditahan selama 5 menit dan dinaikkan $10^{\circ} \mathrm{C} /$ menit sampai $270^{\circ} \mathrm{C}$ ditahan selama 5 menit. Volume injeksi $1 \mu \mathrm{L}$, gas helium digunakan sebagai gas pembawa dengan laju alir 
$1 \mathrm{ml} / \mathrm{min}$. Puncak yang terintegrasi dengan perangkat lunak HP GC Chemstation Operasi (rev. A. 08.00 Agilent Technologies). Konsentrasi individu komponen asam lemak yang dinyatakan sebagai persentase dari daerah puncak spektrum massa diperoleh dengan pencarian pustakanya (data base) pada alat tersebut. Analisis struktural berdasarkan pola fragmentasi spektrum massa, dibandingkan langsung pada profil massa spektral data base dari Institut Nasional Standar dan Teknologi (NIST02.L) dan data base wiley.7n.1 (John Wiley and Sons Inc. Agilent Technologies) seperti yang dijelaskan oleh Oyugi et al. (2011).

\section{HASIL DAN PEMBAHASAN}

Kandungan asam lemak produk fermentasi daging ayam petelur afkir selama penjemuran 5 hari disajikan pada Tabel 1. Profil asam lemak produk daging ayam terfermentasi alami, secara keseluruhan terdeteksi dalam pelarut metanol. Hal ini terkait dengan sifat fisikokimia dan kandungan nutrisi daging yang berasal dari ayam petelur afkir. Asam lemak stearat mengalami penurunan $19,26 \%$ dan kolesterol menurun $65,73 \%$ serta total asam lemak jenuh (SFA) menurun sebesar $17,15 \%$. Namun terdapat peningkatan asam lemak oleat, linoleat (MUFA) dan palmitat berturut-turut: $13,73 \% ; 15,80 \%$ dan $30.05 \%$ sampai akhir pengeringan. Kandungan etil oleat terdeteksi setelah penjemuran 1 sampai 5 hari sebesar $5,68 \%$, dan peningkatan PUFA mencapai $30,68 \%$. Rasio PUFA/SFA $11,30 \%$ dan rasio PUFA/MUFA $12,90 \%$.

Hasil penjemuran atau fermentasi alami pada penelitian ini menunjukkan bahwa total asam lemak jenuh produk daging ayam terfermentasi, turun sebesar $20,23 \%$, sedangkan asam lemak linoleat, mono-unsaturated fatty acid naik mencapai 402,25\%, dan asam lemak oleat, poly-unsaturated fatty acid naik $26,85 \%$. Kenaikan ini terkait dengan tingginya suhu selama penjemuran 5 hari yang memacu aktivitas enzim lipase endogenous bersamaan dengan aktivitas enzim mikroorganisme alami dari bahan baku (daging, komponen bumbu terutama kandungan fenolatnya, pembungkus upih).

Profil asam lemak daging ayam petelur afkir sebagai bahan baku (Okarini et al., 2012), diperoleh kadar lemak terrendah, 1,49\%, daging ayam lokal Bali $(1,73 \%)$, dan dalam daging ayam broiler $(4,70 \%)$. Sangat menarik untuk dicatat bahwa kandungan asam 6-octadecenoic tertinggi ditemukan pada daging ayam petelur afkir $(34,52 \%)$ diikuti oleh daging ayam lokal Bali $(25,63 \%)$ dan daging ayam broiler $(18,77 \%)$. Asam lemak heksadekanoat dalam daging ayam petelur afkir (26,65\%), daging ayam lokal Bali $(21,01 \%)$, dan dalam daging ayam broiler $(17,62 \%)$, kemudian diikuti oleh asam oktadekanoat dalam daging ayam petelur afkir $(16,16 \%)$, daging ayam lokal Bali $(12,26 \%)$ dan daging ayam broiler $(9,80 \%)$. Sementara kandungan kolesterol daging broiler $(33,34 \%)$ dan daging ayam lokal Bali $(23,12 \%)$, dan kecuali kolesterol dalam daging ayam petelur afkir (terdeteksi dalam ekstrak kloroform $30,83 \%)$.

Zanardi et al., (2004) melaporkan suhu lingkungan yang tinggi pada fermentasi sosis, dapat mempercepat proses hidrolisis trigliserida menghasilkan asam-asam lemak, digliserida dan monogliserida dan secara progresif meningkatkan sejumlah perbedaan karbonil produk oksidasi, selanjutnya senyawa karbonil berperan menentukan flavor produk daging fermentasi.

Rasio asam lemak tidak jenuh ganda (PUFA) dengan asam lemak jenuh (SFA) produk fermenasi daging ayam setelah penjemuran 5 hari naik $58,02 \%$, bila dibandingkan dengan daging ayam petelur afkir asalnya. Namun kolesterol produk turun sebesar $65,73 \%$ selama penjemuran. Asam lemak jenuh dan kolesterol turun, meskipun MUFA dan PUFA naik dan hal ini lebih disebabkan oleh endogenous protease dan lipase mikroorganisme alami dari campuran bumbu dan bahan pembungkus, terkait dengan kenaikan populasi ragi, kapang dan asam amino lisin setelah penjemuran 5 hari. Hughes et al. (2002) melaporkan bahwa pola proteolisis dalam sosis fermentasi dipengaruhi oleh beberapa variabel, seperti formulasi produk, kondisi pengolahan, dan penambahan kultur starter. Lisin pada produk daging terfermentasi meningkat dua kali (Okarini et al., 2013), selanjutnya diperlukan sebagai prekursor karnitin yang berperan pada oksidasi asam lemak rantai panjang dalam bentuk asil-karnitin. Berdasarkan aspek katabolisme asam amino, maka metabolit piruvat dan metilketon mengalami oksidasi sempurna pada asam lemak $\beta$ (Stahnke et al., 2002). Fenomena lipolisis, terutama lipase jaringan (Galgano, et al., 2003) dan bakteri lipolitik (Mauriello et al., 2004) bersamaan dengan proteolisis pada tahap awal dan selama 
fermentasi, ketika suhu pengeringan naik.Pengaruh proteolisis pada penelitian ini, asam amino lisin meningkat, sebaliknya arginin menurun sampai akhir penjemuran (Okarini et al., 2013).

Penurunan kadar arginin produk fermentasi daging ayam analog dengan hasil peneliti lain (Diaz et al., 1997 dan Bruna et al., 2000) tentang sosis fermentasi dengan menambahkan ekstrak kapang. Penurunan arginin selama penjemuran, mungkin arginin diubah menjadi senyawa lain seperti ornithin atau $\mathrm{NH}_{3}$ untuk mendukung pertumbuhan mikroorganisme alami. Cocconcelli dan Fontana (2010) melaporkan bahwa arginin diubah menjadi ornithin melalui jalur arginine deiminase (ADI) untuk mendukung pertumbuhan Lactobacillus atau diubah menjadi senyawa glutamat, yang mana tergantung pada aktivitas dari strain kapang dan ragi selama fermentasi daging. Kandungan enzim ADI diketahui sangat jarang dimiliki oleh BAL dengan aktivitas antikarsinogenik, hal ini mungkin peran dari rantai samping arginin hanya mampu sebagai donor ikatan hidrogen pada proses deaminasi oksidatif oleh glutamat dehidrogenase untuk menghasilkan $\alpha$-ketoglutarat. Ansorena, et al. (2001); Hughes et al. (2002) menyatakan bahwa proteolisis dan lipolisis selama fermentasi pada suhu penjemuran yang relatif tinggi, memainkan peran penting dalam degradasi oksidatif untuk konversi asam amino dan asam lemak (asam lemak rantai menengah dan panjang bertindak sebagai prekursor senyawa aroma). Kenaikan lipolisis pada produk daging fermentasi menurut Zanardi et al. (2004) tidak diasosiasikan sebagai ketengikan, namun sebagai fenomena pada produksi senyawa aktif flavor (aroma dan citarasa), terkait dengan penambahan (jumlah dan jenis) lemak dalam formulasi. Lebih lanjut dijelaskan oleh Zhang, (2010) bahwa perubahan biokimia selama fermentasi sangat komplek dalam peningkatan nilai fungsional produk, yang variasinya tergantung pada bahan baku (daging, bumbu-bumbu dan tanpa atau dengan kultur starter) dan teknologi yang diaplikasikan (penggaraman, pengeringan, metode fermentasi dan pengeringan) untuk memproduksi produkproduk daging.

Kenaikan asam lemak oleat, linoleat dan penurunan kolesterol produk daging ayam pada hasil penelitan ini, tampaknya analog dalam hal menjelaskan adanya kenaikan maupun penurunan kadar asam lemak dengan hasil penelitian oleh Muguerza, et al. (2001); Muguerza, et al. (2003) pada sosis tradisional Spanish dengan perlakuan substitusi lemak babi (20-30\%) dengan olive oil sampai $25 \%$. Selanjutnya Elias et al. (2008) menyatakan bahwa kemampuan protein dapat berpotensi sebagai senyawa antioksidan adalah multifungsi untuk menghambat beberapa jalur oksidasi lipida yang berbeda, dan menjadikan komponen penting untuk pertahanan antioksidan pada jaringan biologis dimana makanan diproduksi. Hal ini dikarenakan oleh sifat protein yang unik, dan cara ini dibandingkan dengan antioksidan makanan lain. Bakteri asam laktat, Micrococcaceae, kapang, ragi, dan koliform dari bahan baku tumbuh secara simultan yang saling mempengaruhi satu dengan lainnya pada suhu lingkungan yang relatif tinggi dan pada kondisi anaerob untuk memacu reaksi enzimatis pada pemecahan protein (transformasi asam amino) oleh endogenous protease (endopeptidase, aminopeptidase dan dipeptidase). Selanjutnya reaksi transaminasi pada tahap awal katabolisme asam amino oleh enzim aminotransferase untuk membentuk senyawa aromatik dan memacu aktivitas enzim endogenous lipase pada pemecahan lipida yang dikonversi menjadi asam lemak. 
TABEL 1. Profil asam lemak produk fermentasi daging ayam *

\begin{tabular}{|c|c|c|c|c|c|c|c|}
\hline \multirow{3}{*}{ Komponen $(\%)^{*}$} & \multirow{3}{*}{$\begin{array}{l}\text { Daging } \\
\text { ayam } \\
\text { petelur afkir }\end{array}$} & \multicolumn{6}{|c|}{$\begin{array}{l}\text { Produk daging ayam terfermentasi } \\
\text { (kering sinar matahari) }\end{array}$} \\
\hline & & \multicolumn{6}{|c|}{ Hari ke- } \\
\hline & & $\mathbf{0}(\mathbf{K 0})$ & 1 (K1) & $2(\mathrm{~K} 2)$ & 3 (K3) & $4(\mathrm{K4})$ & 5 (K5) \\
\hline Asam Palmitat & 26,65 & 21,57 & 20,00 & 24,71 & 25,90 & 27,03 & 28,03 \\
\hline Asam Linoleat & 1,78 & 7,72 & 7,29 & 8,44 & 8,51 & 8,32 & 8,94 \\
\hline Asam Oleat & 34,52 & 33,51 & 32,09 & 36,51 & 38,48 & 36,63 & 38,11 \\
\hline Asam Stearat & 16,16 & 7,58 & 5,40 & 5,94 & 6,00 & 6,10 & 6,12 \\
\hline Etil Oleat & 0 & 0 & 2,24 & 3,17 & 11,16 & 4,33 & 5,68 \\
\hline Kolesterol & $\begin{array}{l}51,37 \\
\text { (heksan) }\end{array}$ & 24,60 & 23,40 & 11,36 & 10,98 & 9,60 & 8,43 \\
\hline Piperin & - & - & - & 2,49 & 1,83 & - & - \\
\hline SFA & 42,81 & 29,15 & 25,40 & 30,65 & 31,90 & 33,13 & 34,15 \\
\hline MUFA & 1,78 & 7,72 & 7,29 & 8,44 & 8,51 & 8,32 & 8,94 \\
\hline PUFA & 34,52 & 33,51 & 34,33 & 39,68 & 49,64 & 40,96 & 43,79 \\
\hline PUFA/SFA & 0,81 & 1,15 & 1,35 & 1,29 & 1,56 & 1,24 & 1,28 \\
\hline PUFA/MUFA & 19,39 & 4,34 & 4,71 & 4,70 & 5,83 & 4,92 & 4,90 \\
\hline
\end{tabular}

*) Persen per berat kering; gambar $\mathrm{K}(0)$ - K(5)

Rasio asam lemak tidak jenuh ganda (PUFA) dengan asam lemak jenuh (SFA) produk fermenasi daging ayam setelah penjemuran 5 hari naik $58,02 \%$, bila dibandingkan dengan daging ayam petelur afkir asalnya. Namun kolesterol produk turun sebesar $65,73 \%$ selama penjemuran. Asam lemak jenuh dan kolesterol turun, meskipun MUFA dan PUFA naik dan hal ini lebih disebabkan oleh endogenous protease dan lipase mikroorganisme alami dari campuran bumbu dan bahan pembungkus, terkait dengan kenaikan populasi ragi, kapang dan asam amino lisin setelah penjemuran 5 hari. Hughes et al. (2002) melaporkan bahwa pola proteolisis dalam sosis fermentasi dipengaruhi oleh beberapa variabel, seperti formulasi produk, kondisi pengolahan, dan penambahan kultur starter. Lisin pada produk daging terfermentasi meningkat dua kali (Okarini et al., 2013), selanjutnya diperlukan sebagai prekursor karnitin yang berperan pada oksidasi asam lemak rantai panjang dalam bentuk asil-karnitin. Berdasarkan aspek katabolisme asam amino, maka metabolit piruvat dan metilketon mengalami oksidasi sempurna pada asam lemak $\beta$ (Stahnke et al., 2002). Fenomena lipolisis, terutama lipase jaringan (Galgano, et al., 2003) dan bakteri lipolitik (Mauriello et al., 2004) bersamaan dengan proteolisis pada tahap awal dan selama fermentasi, ketika suhu pengeringan naik.Pengaruh proteolisis pada penelitian ini, asam amino lisin meningkat, sebaliknya arginin menurun sampai akhir penjemuran (Okarini et al., 2013). Penurunan kadar arginin produk fermentasi daging ayam analog dengan hasil peneliti lain (Diaz et al., 1997 dan Bruna et al., 2000) tentang sosis fermentasi dengan menambahkan ekstrak kapang. Penurunan arginin selama penjemuran, mungkin arginin diubah menjadi senyawa lain seperti ornithin atau $\mathrm{NH}_{3}$ untuk mendukung pertumbuhan mikroorganisme alami. Cocconcelli dan Fontana (2010) melaporkan bahwa arginin diubah menjadi ornithin melalui jalur arginine deiminase (ADI) untuk mendukung pertumbuhan Lactobacillus atau diubah menjadi senyawa glutamat, yang mana tergantung pada aktivitas dari strain kapang dan ragi selama fermentasi daging. Kandungan enzim ADI diketahui sangat jarang dimiliki oleh BAL dengan aktivitas antikarsinogenik, hal ini mungkin peran dari rantai samping arginin hanya mampu sebagai donor ikatan hidrogen pada proses deaminasi oksidatif oleh glutamat dehidrogenase untuk menghasilkan $\alpha$-ketoglutarat. Ansorena, et al. (2001); Hughes et al. (2002) menyatakan bahwa proteolisis dan lipolisis selama fermentasi pada suhu penjemuran yang relatif tinggi, memainkan 
peran penting dalam degradasi oksidatif untuk konversi asam amino dan asam lemak (asam lemak rantai menengah dan panjang bertindak sebagai prekursor senyawa aroma). Kenaikan lipolisis pada produk daging fermentasi menurut Zanardi et al. (2004) tidak diasosiasikan sebagai ketengikan, namun sebagai fenomena pada produksi senyawa aktif flavor (aroma dan citarasa), terkait dengan penambahan (jumlah dan jenis) lemak dalam formulasi. Lebih lanjut dijelaskan oleh Zhang, (2010) bahwa perubahan biokimia selama fermentasi sangat komplek dalam peningkatan nilai fungsional produk, yang variasinya tergantung pada bahan baku (daging, bumbu-bumbu dan tanpa atau dengan kultur starter) dan teknologi yang diaplikasikan (penggaraman, pengeringan, metode fermentasi dan pengeringan) untuk memproduksi produkproduk daging.

Kenaikan asam lemak oleat, linoleat dan penurunan kolesterol produk daging ayam pada hasil penelitan ini, tampaknya analog dalam hal menjelaskan adanya kenaikan maupun penurunan kadar asam lemak dengan hasil penelitian oleh Muguerza, et al. (2001); Muguerza, et al. (2003) pada sosis tradisional Spanish dengan perlakuan substitusi lemak babi (20-30\%) dengan olive oil sampai 25\%. Selanjutnya Elias et al. (2008) menyatakan bahwa kemampuan protein dapat berpotensi sebagai senyawa antioksidan adalah multifungsi untuk menghambat beberapa jalur oksidasi lipida yang berbeda, dan menjadikan komponen penting untuk pertahanan antioksidan pada jaringan biologis dimana makanan diproduksi. Hal ini dikarenakan oleh sifat protein yang unik, dan cara ini dibandingkan dengan antioksidan makanan lain. Bakteri asam laktat, Micrococcaceae, kapang, ragi, dan koliform dari bahan baku tumbuh secara simultan yang saling mempengaruhi satu dengan lainnya pada suhu lingkungan yang relatif tinggi dan pada kondisi anaerob untuk memacu reaksi enzimatis pada pemecahan protein (transformasi asam amino) oleh endogenous protease (endopeptidase, aminopeptidase dan dipeptidase). Selanjutnya reaksi transaminasi pada tahap awal katabolisme asam amino oleh enzim aminotransferase untuk membentuk senyawa aromatik dan memacu aktivitas enzim endogenous lipase pada pemecahan lipida yang dikonversi menjadi asam lemak.

\section{SIMPULAN DAN SARAN}

\section{Simpulan}

Profil asam lemak produk daging ayam fermentasi alami mengandung asam lemak stearat $6,12 \%$ dan kolesterol $8,43 \%$ serta total asam lemak jenuh (SFA) $34,15 \%$. Namun demikian asam lemak seperti oleat, linoleat (MUFA) dan palmitat berturut-turut 38,11; 8,94 dan 28,03\%, sedangkan PUFA 43,79\% akhir penjemuran, dan rasio PUFA/SFA sebesar $1,28 \%$ dan rasio PUFA/MUFA sebesar $4,90 \%$. Nilai rasio yang lebih kecil memiliki stabilitas oksidatif yang lebih baik selama penyimpanan daging dan produk olahan daging.

\section{Saran}

Oleh karena itu, dari sudut pandang manfaat kesehatan, dianjurkan untuk menggunakan daging ayam petelur afkir mengandung komponen bioaktif melebihi daging ayam segarnya (lemak dan kolesterol rendah), dan protein (sama dengan kandungan protein daging ayam lokal Bali) serta asam-asam lemak yang diperlukan dapat mencukupi.

\section{DAFTAR PUSTAKA}

Agyei, D. and Danquah, K. 2011. Industrialscale Manufacturing of Pharmaceutical grade Bioactive Peptides, Biotechnol. Adv. 29: 272 -277.

Ansorena , D., Gimeno, V., Astiasarán, I. and Bello, J. 2001. Analysis of Volatile Compounds by GC - MS of A Dry Fermented Sausage: Chorizo de Pamplona. Food Res. Int. 34: 67 - 75.

Arihara, K. 2006a. Strategies for Designing Novel Functional Meat Products, Meat Sci., 74: 219 - 229.

Arihara, K. 2006b. Functional Properties of Bioactive Peptides Derived From Meat Proteins. Chapter 10. In Advanced Technologies for Meat Processing. Boca Raton, Fla: CRC Press, pp.245-273.

Arihara, K. and Ohata, M. 2008. Bioactive compounds in meat. In F. Toldrá (Ed.) Meat Biotechnology,Spinger Science +Business Media,LLC, London pp. 231249.

Bruna, J. M. Fernández, M., Hierro, E.M., Ordóñez, J.-A. and De la Hoz, L. 2000. Combined Use of Pronase E and A Fungal Extract (Pennicillium 
aurantiogriseum) to Potentiate The Sensory Characteristic of Dry Fermented Sausages, Meat Sci. 54: 135 - 145.

Bruna, J. M., Hierro, E. M., De la Hoz, L., Mottram, D. S., Fernández, M. and Ordóñez, J.-A. 2003. Changes in Selected Biochemical and Sensory Parameters As Affected by The Superficial Inoculation of Penicillium camemberti on Dry Fermented Sausages, Int. J. Food Microbiol. 85: 111-125.

Casaburi, A., Aristoy, M.-C., Cavella, S., Di Monaco, R., Ercolini, D.,Toldrá, F. and Villani, F. 2007. Biochemical and Sensory Characteristics of Traditional Fermented Sausages of Vallo di Diano (Southern Italy) as Affected by The Use of Starter Cultures, Meat Sci. 76: 295 307.

Cocconcelli P. S. and Fontana, C. 2010. Starter Culture for Meat Fermentation. In Handbook of Meat Processing. WileyBlackwell. pp 199-218.

Díaz, O., Fernández, M., García de Fernando, GD., De la Hoz, L. and Ordóñez, J-A. 1997. Proteolysis in Dry Fermented Sausages: The Effect of Selected Exogenous Proteases, Meat Sci. 46(1): $115-128$.

Elias, R. J., Kellerby, S. S. and Decker, E. A. 2008. Antioxidant Activity of Proteins and Peptides, Crit. Rev. Food Sci. Nutr. 48: 430 - 441. Accessed 4-04-2012 http://dx.doi.org/10.1080/104083907014 25615.

Galgano, F., Favati, F., Schirone, M., Martuscelli, M. and Crudele, M. 2003. Influence of Indigenous Starter Cultures on The Free Fatty Acids Content During Ripening in Artisan Sausages Produced in The Basilicata Region. Food Techno. Biotechnol. 41: 253 - 258.

Hughes, M. C., Kerry, J. P., Arendt, E. K., Kenneally, P. M., McSweeney, P. L. H. and O'neill, E. E. 2002. Characterization of Proteolysis During The Ripening of Semi-dry Fermented Sausages, Meat Sci. 62: 205

Mauriello, G., Casaburi, A., Blaiotta, G. and Villani, F. 2004. Isolation and Technological Properties of Coagulase Negative Staphylococci from Fermented Sausages of Southern Italy, Meat Sci. 67: $149-158$.
Muguerza, E., Ansorena, D., Bloukas, J.G. and Astiasarán, I. 2003. Effect of Fat Level and Partial Replacement of Pork Backfat with Olive Oil on the Lipid Oxidation and Volatile Compounds of Greek Dry Fermented Sausages, J. Food Sci. 68(4):1531-1536.

Muguerza, E., Gimeno, O., Ansorena, D., Bloukas, J.G. and Astiasarán, I. 2001. Effect of Replacing Pork Backfat with Pre-emulsified Olive Oil on Lipid Fraction and Sensory Quality of Chorizo de Pamplona-a Traditional Spanish Fermented Sausage, Meat Sci. 59:251258.

Okarini Ida Ayu, Hari Purnomo and Aulanni'am. 2012. Chemical Composition and Fatty Acid Profile of Bali Indigenous Chicken, Spent Laying Hen and Broiler Breast Meat (Musculus pectoralis superficialis) Analysed Using Gas Chromatography Mass Spectrophotometry (GC-MS). Proceedings at $15^{\text {th }}$ AAAP Animal Science Congress 26-30 November 2012, Thailand: "Improving Smallholder and Industrial Livestock Production for Enhancing Food Security, Environment and Human Welfare".

Okarini, I.A.; Hari Purnomo; Aulanni am, and Liliek Eka radiati., 2013. Proximate, Total Phenolic, Antioxidant Activity and Amino Acids Profile of Bali Indigenous Chicken, Spent Laying Hen and Broiler Breasst Fillet. Int.J. of Poult.Sci.12(7):415-420.

Oyugi, D. A., Ayorinde, F.O., Gugssa, A., Allen, A. Izevbigie, E.B., Eribo, B. and Anderson, W.A. 2011. Biological Activity and Mass Spectometric Analysis of vernonia-amygdalina Fractions, J. Biosci. Technol. 2(3):287304.

Paramithiotis, S., Drosinos, E. H., Sofos, J. N. and Nychas, G-J. E. 2010. Fermentation: Microbiology and Biochemistry, In: Handbook of meat processing / edited by Fidel Toldrá. Wiley-Blackwell.pp. 185198.

Stahnke, H., Holck, A., Jensen, A., Nilsen, A. and Zanardi, E. 2002. Maturity Acceleration of Italian Dried Sausage by Staphylococcus carnosus Relationship Between Maturity and 
Flavor Compounds, J. Food Sci. 67: 1914 - 1921.

Vass, N., Czegledi, L. and Javor, A. 2008. Significance of Functional Foods of Animal Origin in Human Health, Lucrari stiinfice zootechnie si biotechnologie, 41(2): 263 - 270.

Zanardi, E., Ghidini, S., Battaglia, A. and Chizzolini, R. 2004. Lipolisis and Lipid Oxidation in Fermented Sausages Depending on Different Processing Conditions and Different Antioxidants, Meat Sci. 66: 415 - 423.
Zhang, W., Xiao, S., Samaraweera, H., Lee, E.J. and Ahn, D.U. 2010. Improving Functional Value of Meat Products, Meat Sci. 86:15-31.

Anonymous, 2000. Official Methods of Analysis. Association of Official Analytical Chemist International Gaithersburg, Maryland. $17^{\text {th }}$ edition. USA.

Anonymous, 1960. The Merck Index Of

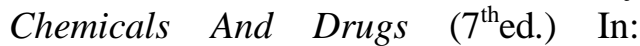
P.G.Stecher (Ed.) pp 97-98. MERCK \& Co., Inc. Rahway, N.J.USA. 
JURNAL KIMIA (JOURNAL OF CHEMISTRY) 13 (1), JANUARI 2019: 44 - 52
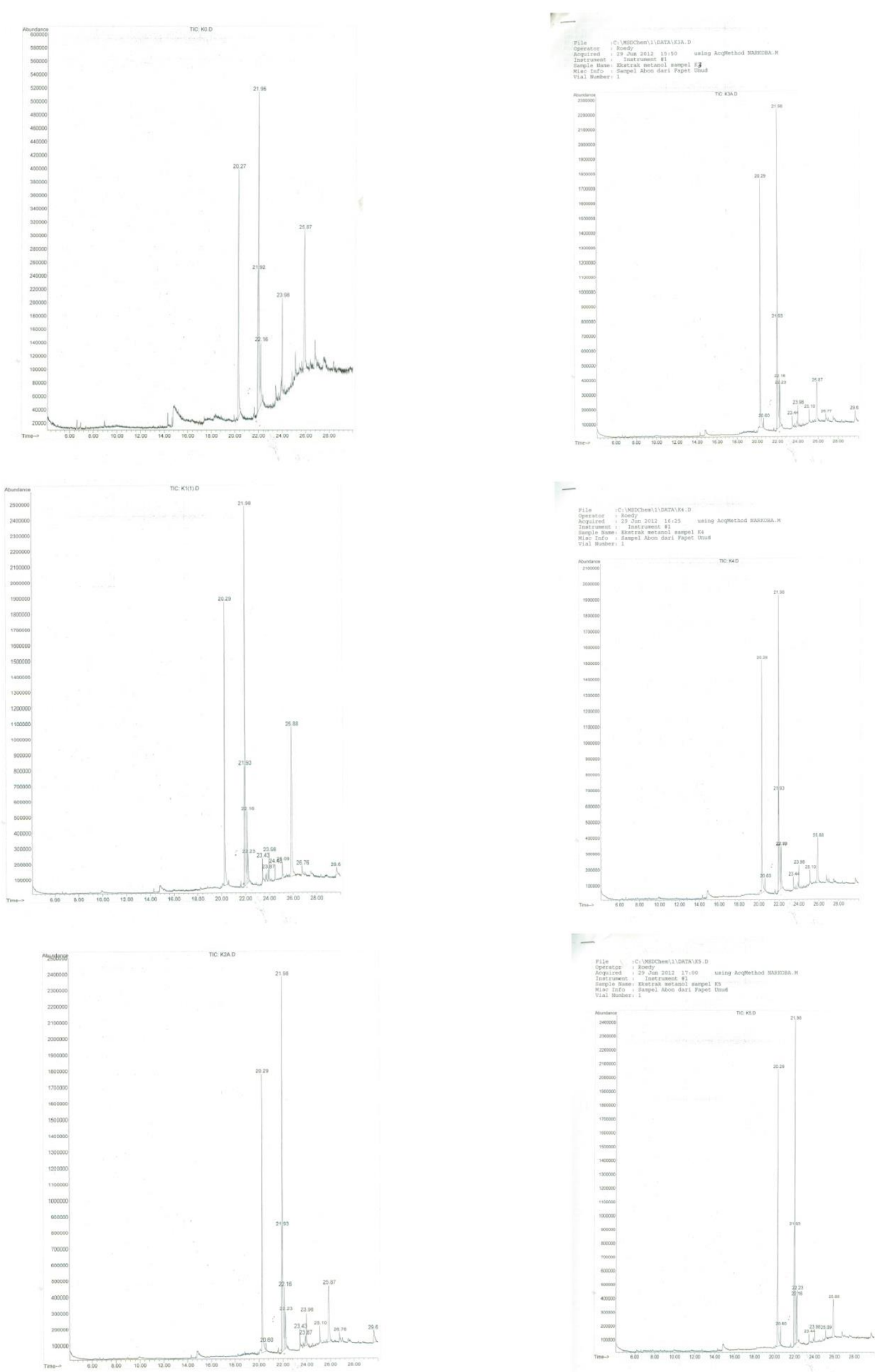